\title{
The Influence of Couples' Living Arrangements on Smoking Habits and Body Weight
}

\author{
Thomas Klein, Ingmar Rapp, Björn Schneider
}

\begin{abstract}
This article examines the influence of intimate relationships on smoking habits and body weight. We differentiated between couples living apart together, cohabitating couples and married couples. The data basis is the Partnermarktsurvey, a German representative telephone survey of 2,002 people aged between 16 and 55 years. The results show that living in a relationship promotes smoking cessation, however only when the partners live together. This indicates that the positive protection effect of relationships on smoking habits is based on the mechanism of social control and social support, which is linked to the context of a shared household. In addition, we observed the homogamy in smoking habits of partners that arises as early as mate selection and is intensified through assimilation processes during the relationship. With regard to body weight, the study shows a weight gain over the course of a relationship which is, however, not greater among married and cohabitating couples than among couples living apart together.
\end{abstract}

Keywords: Relationship living arrangements · Body mass index · Smoking · Partnermarktsurvey $\cdot$ Health behaviour

\section{Introduction}

Recent decades have been marked by a widespread change in couples' living arrangements. Over the course of decreasing marriage rates and increasing divorce rates, married couples have become less common while single living, living apart together and cohabitating couples have become more frequent (cf. Brüderl 2004; Huinink/Konietzka 2007: 75; Klein 1999b). For example, the percentage of long-term single people in western Germany has risen from only about 5 percent among women and men born in the year 1930 to almost 20 percent among women born in 1960 and to nearly 30 percent among men born in 1960 (Engst/er/Menning 2003: 68).

Parallel to this phenomenon, the health behaviour of the population has changed. Body weight, which is a good indicator of eating and physical activity behaviours, 
has risen sharply on average (e.g. Mensink et al. 2005; Robert Koch-Institut 2009). For example, the average body mass index (BMI) of the adult population rose from 24.3 to 26.3 between 1978 and 2009 (Statistisches Bundesamt 2010). ${ }^{1}$ Smoking habits have also undergone a change, but less uniform in nature. In recent years the smoking rate among men has dropped steadily. That of women, by contrast, is not in decline, yet remains lower than that of men (Statistisches Bundesamt 2006). Both excess body weight and smoking are frequent causes of chronic illnesses and significantly influence the health and mortality of the population (Ezzati/Lopez 2003; Hauner 1996).

With regard to the better health of married people (Brockmann 2008; Gove 1973; Wilson/Oswald 2005), the question arises of whether the change in couples' living arrangements perhaps contributes to explaining changes in health behaviour in the population. Very little can be asserted about this aspect since only very little is known about the health effects of relationship types outside of marriage.

In this article, to examine the influence of couples' living arrangements on health we look at two of the most important health aspects or indicators of health-relevant behaviour - the body mass index, which represents body weight in relation to height, and smoking habits. A consideration of smoking and body weight or BMI is also of interest because for both aspects of health behaviour different correlations are observed with relationship status. Unlike many earlier studies on the influence of couples' living arrangements on health behaviour, which differentiate only between married and unmarried people, in this article we differentiate between married couples, cohabitating couples, couples living apart together (LAT) and singles.

\section{Empirical findings, explanatory approaches and hypotheses}

First, we will portray existing findings on the correlation between couple's living arrangements and smoking habits as well as body weight. Research has focussed on marriage in this respect. We will then discuss competing explanatory patterns and generate empirically testable hypotheses.

The results for Germany consistently report that married people smoke less than non-married people (Helmert et al. 2001; Lampert/Burger 2005; Mons 2007; Schulze/Lampert 2006). Also, there is a correlation between smoking habits of partners (Sutton 1980; Venters et al. 1984; Vink et al. 2003).

The empirical results on the correlation between body weight and couples' living arrangements are, by contrast, inconsistent. Some studies show an on average higher BMI of married people compared to unmarried ones (Heineck 2006; Statistisches Bundesamt 2006; Ross/Mirowsky 1983). Other studies are unable to identify any differences (Kittel et al. 1978; Register/Williams 1990) or ascertain higher weights among unmarried people than married ones (Noppa/Bengtsson 1980; Sund

1 The BMI value for the year 1978 is based on the 1978 German Microcensus and was provided to us courtesy of the Federal Statistical Office (Statistisches Bundesamt 2010). 
et al. 2010). Other findings indicate that even the transition to cohabitation is accompanied by a rise in the BMI (Averett et al. 2008; The/Gordon-Larsen 2009). Finally, existing studies show a similarity in the body weight of partners (Falba/Sindelar 2008; Knuiman et al. 1996a; Knuiman et al. 1996b).

Four approaches can be considered which might explain these results. On the one hand, we must differentiate between causal effects of living arrangements on health behaviour and selection processes on the dating market. In the first case, couples' living arrangements cause a change in health behaviour (cf. the following chapter 2.1-2.4). In the second case the causal direction is reversed, in that health behaviour influences the probability of finding a partner (Chapter 2.5). On the other hand, we must differentiate between assimilation processes of the partners and assortative matching (i.e., individuals with similar characteristics start a relationship more often), whereby similarities in the health behaviour of each partner can be explained. For example, the partners' health behaviour may become aligned first during the relationship (Chapter 2.6) or similarity can already determine mate selection and therefore already exist at the beginning of the relationship (Chapter 2.7).

\subsection{Social control and social support}

An effect of couples' living arrangements on health behaviour is anticipated mainly based on social control and social support by the partner (cf. Umberson 1987; Umberson 1992). From the rational-choice perspective, we are all interested in a partner who behaves in a health-conscious way, regardless of our own health behaviour (Duncan et al. 2006: 692), since health is a form of human capital (cf. Becker 1993), which is the basis, for example, for achieving educational returns on the employment market (cf. Gross/Groß 2008: 253). Therefore, the benefit of a relationship for an individual also depends on the health behaviour of the partner. If the partner has health problems or illness, this leads to losses or costs (e.g. through loss of income or expenses for medical care), which could have been avoided through early healthful behaviour. For this reason, partners invest time and energy in supporting and controlling their partner, which enables health motivating behavioural changes.

In addition to this direct influence of social control and social support by the partner (known as the main effect hypothesis), there is also a possible indirect effect on health behaviour (known as the buffering hypothesis). Social support in a relationship can buffer stress (e.g. Cohen/Wills 1985), which may otherwise be reacted to with suboptimal coping strategies or with health-detrimental behaviour such as greater nicotine consumption (cf. Ikard et al. 1969; Stein et al. 2008; Wills/Shiffman 1985), a high-calorie or high-fat diet (cf. Laitinen et al. 2002; Ng/Jeffery 2003) or possibly also with lessened physical activity (cf. Klein 2009; Steptoe et al. 1996). These stress reactions can partly be considered dysfunctional coping behaviours, which reduce stress for the short term (subjectively) (cf. on smoking Parrott 1994). According to this hypothesis, the protection effect of a relationship arises only indirectly in the context of external stress factors. The protection influences of social support and social control in the relationship are illustrated in Table 1 by plus signs. 
Tab. 1: Hypotheses on the influence of the type of relationship on smoking habits and body weight

\begin{tabular}{|c|c|c|c|c|}
\hline Explanatory approach & $\begin{array}{l}\text { Protection effect } \\
\text { on smoking }\end{array}$ & $\begin{array}{l}\text { Protection effect } \\
\text { on body weight }^{1}\end{array}$ & $\begin{array}{l}\text { Differences in the } \\
\text { protection effects } \\
\text { between couples' living } \\
\text { arrangements }\end{array}$ & Alternative hypothesis ${ }^{3}$ \\
\hline $\begin{array}{l}\text { Social control and } \\
\text { social support }\end{array}$ & + & + & $\mathrm{M}=\mathrm{Co}>\mathrm{LAT}>\mathrm{S}$ & \\
\hline Living in a relationship & 0 & - & $\mathrm{M}=\mathrm{Co}<\mathrm{LAT}=\mathrm{S}$ & \\
\hline Social norms & + & 0 & $\mathrm{M}>\mathrm{Co}=\mathrm{LAT}=\mathrm{S}$ & \\
\hline $\begin{array}{l}\text { Release from the } \\
\text { dating market }\end{array}$ & 0 & - & $\mathrm{M}<\mathrm{Co}<\mathrm{LAT}<\mathrm{S}$ & \\
\hline Relationship selection & + & + & $\mathrm{M}=\mathrm{Co}=\mathrm{LAT}>\mathrm{S}$ & $\mathrm{M}>\mathrm{Co}>\mathrm{LAT}>\mathrm{S}$ \\
\hline Adverse selection & - & - & $\mathrm{M}=\mathrm{Co}=\mathrm{LAT}<\mathrm{S}$ & $\mathrm{M}<\mathrm{Co}<\mathrm{LAT}<\mathrm{S}$ \\
\hline Assimilation & $+/^{2}$ & $+/-^{2}$ & $\begin{array}{c}M=\text { Co }>\text { LAT } \\
\text { resp. } M=\text { Co }<\text { LAT }\end{array}$ & \\
\hline Assortative matching & + & + & $\mathrm{M}=\mathrm{Co}=\mathrm{LA} T$ & \\
\hline
\end{tabular}

1 + positive protection effect; 0 no effect; - negative protection effect

2 Effect in relation to smoking or diet and exercise behaviour of partner

${ }^{3} \mathrm{M}$ - Married; Co - Cohabitating; LAT - Living apart together; S - Single

Source: own design

As for differences between couples' living arrangements, we anticipate an effect on health behaviour primarily among married and cohabitating couples, since living together in one household improves opportunities for social support and social control and reduces its costs (cf. Duncan et al. 2006: 692). By contrast, we anticipate no or only a minor protection effect of living apart together. These hypotheses concerning the differences in the protection effect of couples' living arrangements are illustrated in Table 1 by symbols (less than, greater than, equal).

\subsection{Living in a relationship}

Unlike other health indicators, protection from excess weight is contested in various ways. As for caloric intake, a relationship is accompanied by more frequent food intake (Craig/Truswell 1988; Davis et al. 1985; Jeffery/Rick 2002; MacPherson 1983), and meals eaten in company tend to be more rich (de Castro/de Castro 1989; Jeffery/Rick 2002). This negative protection effect is possibly intensified by the fact that regular shared meals are among relationship role obligations (Averett et al. 2008; Sobal et al. 1992: 916). But also with regard to caloric consumption, protection effects are negative if a relationship is accompanied by a less active lifestyle (Klein 2009; Sobal et al. 1992: 920).

The existence of a mutual household appears decisive for the listed negative protection effects. Ultimately, regular shared meals largely depend on whether the 
partners live together. Among people living apart together, by contrast, no negative protection effect on the BMI is anticipated in this regard (see Table 1).

\subsection{Social norms}

Various relationship types are possibly linked to social norms that influence health behaviour. This is based on the view that health-detrimental behaviour, which is linked to the "wilder" life of singles, contradicts a lifestyle in a relationship (Duncan et al. 2006: 692). One example is that of mothers who smoke. The relationship dependence of normative models affect drug consumption in particular (including smoking), but less so nutritional and exercise behaviour. Therefore, on this basis protection effects are anticipated only for smoking, but not for body weight (see Table 1).

The greatest degree of union formation in the living arrangements of couples is to be seen in marriage and it also has the greatest and therefore deepest roots of concrete social norms in society. Other relationship types, by contrast, have only become more widespread in recent decades and are accompanied by less distinct normative ideals (Duncan et al. 2006: 692). We therefore assume that normative protection effects are effective primarily among married couples (see Table 1).

\subsection{Release from the dating market}

A fourth explanatory approach for the relationship effect on health behaviour refers to dating market processes. While searching for a partner, one makes efforts to behave in ways that increase one's own attractiveness and these include healthful behaviours. When entering a relationship, people are released from direct competition on the dating market, possibly combined with a decline in health awareness (cf. Averett et al. 2008). This has been empirically confirmed with regard to body weight (Klein 2011). With regard to smoking, however, the dating market argument is hardly of quantitative relevance since most people begin smoking before the age of about 20 years (cf. Statistisches Bundesamt 2006: 63-64), but stabile relationships are increasingly not begun until later ages.

Since the stability of couple relationships increases with an increasing degree of union formation, married people are most likely to expect a lasting release from the dating market and people in living apart together relationships are the least likely. We therefore anticipate correspondingly tiered negative protection (see Table 1).

\subsection{Relationship selection}

Contrary to the above explanatory approaches, the selection hypothesis assumes that it is not the relationship that affects health, but conversely that those in better health have better chances of finding a partner (e.g. Goldman 1993; Unger 2008). While the relevance of health selection on the dating market is fiercely debated (also with regard to the fact that the effects of behaviour on the health of young adults, who focuss on the choice of a life mate, are hardly visible), selection according to 
physical attractiveness, which also depends on the body weight, is empirically well substantiated (Carmalt et al. 2008; Kurzban/Weeden 2005; Sobal 1999). There are also initial empirical indications of differentiation of dating market chances according to smoking status for the reason that non-smokers tend to be more attractive partners due to better health and the costs of tobacco products (cf. Klein/Rüffer 2001: 174).

Since both body weight and smoking habits are obvious, we can assume that selection is initiated during mate selection and no longer plays much of a role once a couple moves in together or marries (see Table 1). Alternatively, however, we cannot exclude that the long term during which the health behaviour examined here affects health also contributes to selection in the transition to a more stabile type of relationship. As a consequence of this tiered selection, married couples would have the lowest smoker quota and the lowest body weight, followed by cohabitating couples and then by couples living apart together (see Table 1).

Finally, we must also consider adverse selection. This is based on the idea that people with poor health behaviour enter into marriage and cohabitation precisely due to their protection effects and show a lesser separation rate. A higher tendency to marry is empirically confirmed for men in poor health (Lillard/Panis 1996) and for smokers between the ages of 16 and 23 years (Cheung/Sloggett 1998). But high body weight is also an incentive to stabilise a relationship through cohabitation and marriage due to the lesser chances of finding a new partner after separation. Based on tiered adverse selection we anticipate the lowest smoking rate and lowest body weight among singles, followed by couples living apart together, cohabitating couples and finally by married couples (see Table 1).

\subsection{Relationship assimilation processes}

One scarcely investigated extension of the established protection hypothesis raises the question to what extent relationship influences on health differ depending on the characteristics of the partner because an assimilation might occur in the health behaviours of partners. We differentiate between three assimilation processes (K/ein 2011): (1) the standardisation of health-relevant living conditions, in particular the level of prosperity and associated possibilities for a healthy lifestyle and medical care. (2) An assimilation in the lifestyles of the partners has a direct effect on health-relevant behaviour. (3) In addition to this direct behavioural influence there are different mutual normative guidelines and demands depending on the configuration of the partners.

The relevance of assimilation processes for health behaviour has hardly been analysed. With regard to smoking, at the latest starting at an age range in the midtwenties only cessation behaviour is quantitatively significant, i.e. an assimilation of smokers to a non-smoking partner. Indeed empirical studies indicate that people are more likely to quit smoking if the partner is a non-smoker (Dollar et al. 2009; McBride et al. 1998; Mons 2007). With regard to body weight, the close links between caloric intake and calorie consumption with the shared lifestyle make it likely that lifestyle assimilation processes are more decisive for body weight than for other 
aspects of health behaviour. In a current study (Klein 2011), no indication was found of partners' weights adapting to one another - this study, however, does not differentiate according to types of relationships.

As for the question of whether assimilation to the health behaviour of the partner differs depending on the type of relationship, only few results presently exist. It was shown that assimilation in obesity between the partners arose as a result of cohabitation (cf. The/Gordon-Larsen 2009).

\subsection{Assortative matching}

Assortative matching is an alternative explanation for the similarity in the health behaviours of partners. According to this, not only people with healthful behaviour would find it easier to find a partner (relationship selection), but also people with similar health behaviour would tend to enter into relationships with one another. Assortative matching may be based on a principle of homogamy in mate selection, according to which potential partners with similar characteristics - e.g. similar BMI or smoking habits - are perceived as more attractive. On the other hand, homogamy can arise based on the principle of maximisation (i.e., the search for the most attractive partner). In this case, the competition for attractive partners also leads to homogamous relationships, when each person rejects a relationship with someone who is less attractive than they are (cf. Klein 2000).

Since weight and smoking habits are obvious characteristics of a potential partner, assortative matching takes effect during mate selection, whereas we expect hardly any differences in similarity between relationship types. This assumption is also confirmed by findings which show that with regard to other obvious traits such as education and religion, homogamy occurs during mate selection and not only later upon entry into marriage (Blackwell/Lichter 2004; Klein 1999a). There are studies which confirm this for smoking habits (Agrawal et al. 2006; Clark/Etilé 2006).

\section{Data and methods}

This analysis is based on the data of the Partnermarktsurvey (see Klein et al. 2010: 203-204), a representative telephone survey of 2,002 German heterosexuals aged between 16 and 55 years. They were recruited using random telephone numbers between January and August 2009. The respondent rate was 40 percent. It was a cross-sectional survey that was supplemented with retrospective questions on the current relationship and on health behaviour. Such quasi-longitudinal data on relationship biographies can be considered sufficiently reliable despite the associated problems with retrospective questions (cf. Klein/Fischer-Kerli 2000).

One of the advantages of the data is that couples living apart together are also included, and not only cohabiting and married couples. Another is that the data also contain the partner's smoking habits and body mass index. It is also unique in that it provides information on health behaviour precisely at the beginning of the 
relationship (not just, for example, during the year the relationship began), making it possible to analyse changes during the relationship.

Smoking status (smokers vs. non-smokers) and body mass index (BMI) are analysed as dependent variables at the time of the interview. The BMI depicts the ratio of weight and height and is calculated as follows: BMI = weight in $\mathrm{kg} /$ (height in $\mathrm{m})^{2}$. The information on body weight and height, as well as all other information, is based on self-reporting. ${ }^{2}$ Other dependent variables included in the analysis are changes in smoking habits and changes in body weight since the beginning of the relationship. We investigated whether people ceased smoking since the beginning of the relationship. This information is the result of two questions: One on the current smoking status as well as one on the smoking status at the beginning of the relationship. The relevant analyses refer only to people who were smokers at the beginning of their current relationship. ${ }^{3}$ We also examine whether people have gained considerable weight since the beginning of the relationship. This is included via the following question: "When you entered into your relationship with [name of the partner], did you weigh about the same as you do now?" with the response categories: "Yes, about exactly the same," "No, far less" and "No, far more."4 The partner's smoking habits at the beginning of the relationship are analysed as another dependent variable.

The independent variables with regard to the current relationship status differ between not in a relationship, LAT relationship, cohabitation and marriage. ${ }^{5}$ The partner's smoking habits and the changes to this during the relationship are asked similarly to that of the respondent.

The control variables used are gender, age, educational level (in years) and relationship duration (in years). To calculate the years of education, the certificates of the German school types were converted as follows (cf. Jöckel et al. 1997): No certificate (including those still in school) $=8$ years; Volksschule or Hauptschule $=9$ years; Realschule or Polytechnische Oberschule 10 ${ }^{\text {th }}$ grade (before 1965: $8^{\text {th }}$ grade) $=10$ years; Fachhochschulreife or certificate from a Fachoberschule $=12$ years and Hochschulreife $=13$ years.

2 Comparative calculations with the 1998 Bundesgesundheitssurvey (cf. Thefeld et al. 1999) not shown here show that the self-reported body weight in the telephone survey of the Partnermarktsurvey is slightly lower than actual measurements on the scale. However, we do not assume that structural differences are also affected by this. This would only be the case if the underassessment, e.g. for married people, were greater or lesser than for cohabiting people. As for the self-reported smoking behaviour, similarly, we must take account for an underassessment of smoking prevalence, but not that this affects differences between groups.

3 We do not analyse smoking that begins during relationships, since this is very rare and the relevant case number of 35 people is too small.

4 Weight loss in relationships is not analysed since considerable weight loss during relationships is rare due to the known age-weight curve and because the relevant case number of 64 people is too small.

5 All married people are included in the "married" category regardless of whether they currently live with their spouse or not. The latter is the case for 17 people. 
Tab. 2: $\quad$ Shares and mean values of the dependent and independent variables and number of missing values

\begin{tabular}{|c|c|c|}
\hline & $\begin{array}{c}\text { Shares/ } \\
\text { Mean value }\end{array}$ & $\begin{array}{c}\text { Number of } \\
\text { cases }\end{array}$ \\
\hline \multicolumn{3}{|l|}{ Dependent variables } \\
\hline \multicolumn{3}{|l|}{ Current smoking status } \\
\hline Smoker & 0.31 & 619 \\
\hline Non-smoker & 0.69 & 1378 \\
\hline Missing value & & 3 \\
\hline $\begin{array}{l}\text { BMI } \\
\text { Missing value }\end{array}$ & 24.37 & $\begin{array}{r}1946 \\
54\end{array}$ \\
\hline \multicolumn{3}{|l|}{ Quit smoking during current relationship } \\
\hline No & 0.54 & 378 \\
\hline Yes & 0.46 & 316 \\
\hline Missing value/not applicable & & 1306 \\
\hline \multicolumn{3}{|l|}{ Gained weight during current relationship } \\
\hline No & 0.55 & 804 \\
\hline Yes & 0.45 & 656 \\
\hline Missing value/not applicable & & 540 \\
\hline \multicolumn{3}{|c|}{ Smoking status at the beginning of current relationship } \\
\hline Smoker & 0.52 & 767 \\
\hline Non-smoker & 0.48 & 695 \\
\hline Missing value/not applicable & & 538 \\
\hline \multicolumn{3}{|l|}{ Independent variables } \\
\hline \multicolumn{3}{|l|}{ Gender } \\
\hline Male & 0.40 & 806 \\
\hline Female & 0.60 & 1194 \\
\hline Age & 39.08 & 2000 \\
\hline \multicolumn{3}{|l|}{ Current relationship status } \\
\hline Not in relationship & 0.27 & 537 \\
\hline Living apart together & 0.14 & 279 \\
\hline Cohabitating & 0.10 & 196 \\
\hline Married & 0.49 & 988 \\
\hline $\begin{array}{l}\text { Duration of relationship in years } \\
\text { Missing value/not applicable }\end{array}$ & 16.09 & $\begin{array}{r}1450 \\
550\end{array}$ \\
\hline \multirow{2}{*}{\multicolumn{3}{|c|}{$\begin{array}{l}\text { Changes in smoking behaviour of partner during the relationship } \\
\text { Partner did not smoke during relationship or quit }\end{array}$}} \\
\hline & & \\
\hline smoking & 0.70 & 1017 \\
\hline Partner began smoking during relationship & 0.02 & 30 \\
\hline Partner has always been a smoker & 0.28 & 412 \\
\hline Missing value/not applicable & & 541 \\
\hline \multicolumn{3}{|c|}{ Partner's smoking behaviour at the beginning of the relationship } \\
\hline Smoker & 0,50 & 725 \\
\hline Non-smoker & 0.50 & 735 \\
\hline Missing value/not applicable & & 540 \\
\hline
\end{tabular}

Source: Partnermarktsurvey, own calculations 
The relationship duration was first calculated to the exact day based on the information provided at the time of the interview and at the beginning of the relationship. Since for the beginning of the relationship only the year and month are known, the middle of the month (the $16^{\text {th }}$ day of the month) was assumed as the beginning of the relationship. If only the year was cited for the beginning of the relationship, it was set on 1 July of the respective year. In four cases in which the relationship began during the month of the survey, the beginning of the relationship was set at the midpoint between the beginning of the month and the date of the interview. To convert this to precise year information the exact day calculation of the relationship duration was divided by 365.25 .

Of the 2,002 cases in the Partnermarktsurvey, two cases were excluded from the analyses because the current relationship status was not known. Other exclusions resulted from missing values for the respective dependent variable. Also cases with missing values for other independent variables besides relationship status were excluded in the affected analyses. Table 2 shows the number of missing values for all dependent and independent variables.

After exclusion of all cases with missing values (on smoking status or other variables included in the analyses), 1,964 people are available for the analyses of current smoking status. In addition, 1,914 people are available for the analyses of the current BMI, 673 people for the analyses of smoking cessation during the relationship, 1,425 people for the analyses of a considerable weight gain during the relationship as well as 1,424 people for the analyses of smoking habits at the beginning of the relationship. Table 2 also shows the mean values and shares of the dependent and independent variables.

OLS regression (ordinary least squares) was used to analyse the relationship effects on the BMI. The analyses of all other dependent variables are based on logit regression models.

\section{$4 \quad$ Results}

Table 3 first compares the smoking habits and the BMI based on the couples' living arrangements (including those without a partner). ${ }^{6}$ The reference group includes those who are in a relationship but do not live together. The choice of this reference group also reveals any differences between the living arrangements with partners that do not differ through initial relationship selection (because the living arrangements of all those in a relationship might have gone through a possible initial selection).

6 The influences of age, gender and educational level are kept statistically constant. This is important because smoking rates diverge considerably according to age, gender and education (cf. for an overview Statistisches Bundesamt 2006; Schulze/Lampert 2006). The inclusion of the squared age takes the non-linear correlation between age and smoking or BMI into account. 
Tab. 3: Relationship effects on smoking status (logit regression, logit coefficients) and on BMI (OLS regression)

\begin{tabular}{lcc}
\hline Influencing factor & Smoking & BMI \\
\hline Man $^{1}$ & $0.34^{* *}$ & $1.85^{* * *}$ \\
Age & $0.12^{* * *}$ & $0.41^{* * *}$ \\
Age ${ }^{*}$ Age & $-0.001^{* * *}$ & $-0.004^{* * *}$ \\
Years of education $^{*}$ & $-0.17^{* * *}$ & $-0.36^{* * *}$ \\
Without a partner $^{2}$ & 0.07 & 0.35 \\
Cohabiting $^{2}$ & -0.12 & 0.40 \\
Married $^{2}$ & $-0.61^{* * *}$ & $0.64^{*}$ \\
Constant & -0.91 & $18.37^{* * *}$ \\
McFadden $^{2}$ (smoking) or corrected $\mathrm{r}^{2}$ (BMI) & 0.03 & 0.16 \\
Number of cases & 1964 & 1914 \\
\hline
\end{tabular}

Significance levels: ${ }^{* *} \mathrm{p}<0.001 ;{ }^{* *} \mathrm{p}<0.01 ;{ }^{*} \mathrm{p}<0.05 ;+\mathrm{p}<0.10$

${ }^{1}$ Reference category: woman

2 Reference category: Living apart together

Source: Partnermarktsurvey, own calculations

As illustrated by the left column of Table 3, only married people smoke significantly less and therefore profit from a protection effect. The low, statistically insignificant difference in smoking habits between those with partners living apart together (LAT) and those without partners contradicts the hypothesis of initial selection - i.e. preference given to non-smokers on the dating market. ${ }^{7}$

The results for body weight (right column of Table 3) are similar. Here, too, only marriage shows a significant effect. Married people have a higher BMI than those with partners living apart together. There is no statistically significant BMI difference between people without a partner, those in LAT relationships and cohabiting people (Table 3). The statistically insignificant difference between people without a partner and those with partners living apart together contradicts the hypothesis of initial relationship selection of people with a lower BMI. Then again we cannot exclude that the initial selection of slimmer people in relationships is not neutralised by a negative protection effect through release from the dating market.

While Table 3 illustrates the current smoking habits and current BMI, the following analyses use the longitudinal information of the data and examine changes in smoking habits and body weight over the course of the respondents' current relationship. Only those are included who are in a relationship. The respective results are shown in the left columns of Tables 4 and 5 (Model 1). Table 4 looks at the

$\overline{7}$ Cf. however the ensuing analyses in Table 4 for restrictions. 
Tab. 4: Determinants of smoking cessation during the relationship - the influence of relationship status, relationship duration and the partner's smoking habits (logit regression, logit coefficients) ${ }^{1}$

\begin{tabular}{|c|c|c|c|c|}
\hline Influencing factor & Model 1 & Model 2 & Model 3 & Model 4 \\
\hline $\operatorname{Man}^{2}$ & $-0.44 * *$ & $-0.37^{*}$ & $-0.51 * *$ & $-0.51^{* *}$ \\
\hline Age & -0.08 & -0.01 & -0.02 & -0.03 \\
\hline $\mathrm{Age}^{*} \mathrm{Age}$ & 0.00 & 0.00 & 0.00 & 0.00 \\
\hline Years of education & $0.10+$ & $0.09+$ & 0.07 & 0.07 \\
\hline Cohabiting $^{3}$ & $0.95^{* *}$ & $0.69+$ & $0.88^{*}$ & 0.84 \\
\hline Married $^{3}$ & $1.52^{* * *}$ & $0.78^{*}$ & $0.72 *$ & $1.01+$ \\
\hline Duration of relationship & & $0.06 * * *$ & $0.05 * * *$ & $0.05^{* * *}$ \\
\hline $\begin{array}{l}\text { Partner did not smoke during } \\
\text { relationship or quit smoking }\end{array}$ & & & $1.29 * * *$ & $1.56^{* *}$ \\
\hline $\begin{array}{l}\text { Partner began smoking during } \\
\text { relationship }{ }^{4}\end{array}$ & & & -0.14 & -0.17 \\
\hline $\begin{array}{l}\text { Cohabitating }{ }^{3 *} \text { Partner did not } \\
\text { smoke during relationship or quit } \\
\text { smoking }^{4}\end{array}$ & & & & 0.22 \\
\hline $\begin{array}{l}\text { Marriage }{ }^{3 *} \text { Partner did not smoke } \\
\text { during relationship or quit }\end{array}$ & & & & \\
\hline smoking $^{4}$ & & & & -0.41 \\
\hline Constant & -1.36 & -2.18 & $-2.41+$ & $-2.45+$ \\
\hline McFadden $r^{2}$ & 0.08 & 0.10 & 0.15 & 0.15 \\
\hline Number of cases & 673 & 673 & 673 & 673 \\
\hline
\end{tabular}

Significance levels: ${ }^{* *} \mathrm{p}<0.001 ;{ }^{*} \mathrm{p}<0.01 ;{ }^{*} \mathrm{p}<0.05 ;+\mathrm{p}<0.10$

1 The analyses only refer to people in relationships (i.e. not singles) as well as to people who smoked at the beginning of the relationship.

${ }^{2}$ Reference category: Woman

${ }^{3}$ Reference category: Living apart together

${ }^{4}$ Reference category: Partner always smoked

Source: Partnermarktsurvey, own calculations

determinants of smoking cessation among those who smoked at the beginning of the relationship. 8

Our analysis revealed that smoking cessation during relationships is more frequent both among cohabiting couples and married people than couples living apart together (which form the reference group). In addition, the protection effect is the greatest among married people. With regard to a considerable weight gain during the relationship (Model 1 in Table 5) only married people have a greater chance than couples living apart together.

$\overline{8}$ The onset of smoking among non-smoking adults is quantitatively insignificant and is not examined here due to the low number of cases (see point 3 above). 
Tab. 5: Determinants of considerable weight gain during the relationship - the influence of relationship status and relationship duration (logit regression, logit coefficients) ${ }^{1}$

\begin{tabular}{lcc}
\hline Influencing factor & Model 1 & Model 2 \\
\hline Man $^{2}$ & -0.16 & -0.06 \\
Age & 0.06 & $0.14^{* *}$ \\
Age $^{*}$ Age & -0.0004 & $-0.0018^{* *}$ \\
Years of education $^{\text {Cohabiting }}{ }^{3}$ & $-0.17^{* * *}$ & $-0.16^{* * *}$ \\
Married $^{3}$ & 0.32 & 0.04 \\
Duration of relationship & $0.99^{* * *}$ & 0.13 \\
Constant & & $0.06^{* * *}$ \\
McFadden $\mathrm{r}^{2}$ & -0.90 & $-1.93^{*}$ \\
Number of cases & 0.08 & 0.11 \\
\hline
\end{tabular}

Significance levels: *** $p<0.001 ;{ }^{* *} p<0.01 ;{ }^{*} p<0.05 ;+p<0.10$

${ }^{1}$ The analyses only refer to people in relationships (i.e. not singles).

${ }^{2}$ Reference category: Woman

${ }^{3}$ Reference category: Living apart together

${ }^{4}$ Reference category: Partner did not gain weight during relationship or lost weight

Source: Partnermarktsurvey, own calculations

Nevertheless, a problem posed by Model 1 (as well as by Table 3) is that the three couples' living arrangements exhibit very different relationship durations. While relationships of people who do not share a household usually are comparatively short-lived, on average married people have the longest relationship durations. We must therefore clarify whether (and to what extent) the differences in the protection effect (smoking cessation) or negative protection (weight gain) truly correlate with the type of relationship or rather can be explained by the different relationship duration: Since a longer relationship duration is accompanied per se with a greater probability of behavioural change during the relationship due to the longer period of time involved. Model 2 of Tables 4 and 5 therefore also includes the relationship duration and thus is kept constant. As shown in Tables 4 and 5 (Model 2), the differences between the couples' living arrangements shrink greatly with the given relationship duration. ${ }^{9}$

Nonetheless even after controlling for relationship duration (Table 4, Model 2) there is a greater chance of smoking cessation in relationships for married and co-

9 Analyses not shown here reveal that the effect of the duration of a relationship on considerable weight gain during the relationship is significantly greater among men than women. 
habitating people compared to people in LAT relationships. The difference between cohabiting people and people in LAT relationships are, however, only of weak statistical significance. The similarity in the effects for married and cohabiting couples supports our hypothesis that social control and social support are decisive for the influence of the type of relationship on smoking habits, since living together in one household improves opportunities for control as well as support. By contrast, social norms, which promised protection effects mainly for married couples, appeared to have merely minor significance. Tiered relationship selection is a possible alternative explanation, however, in which smoking cessation increases the probability of moving in together and marrying.

With regard to considerable weight gain during the relationship, there are no differences revealed between the three types of couples' living arrangements after controlling for relationship duration (Table 5, Model 2). The greater chance of married people to exhibit weight gain during the relationship compared to people in LAT relationships (Model 1) can be explained by the far longer average relationship durations of married couples. The probability of weight gain during the relationship increases trivially with a longer relationship duration.

Model 3 of Table 4 additionally examines the assimilation hypothesis for smoking habits, for which information is also available (unlike the BMI) for the beginning of the relationship. For this purpose the model includes two additional variables (in addition to Model 2 of Table 4) that show the smoking habits of the partner at the beginning of the relationship and changes during the relationship. The first variable measures whether the partner of the respondent was always a non-smoker during the relationship or gave up smoking over the course of the relationship. The second variable measures whether the partner began smoking during the relationship. ${ }^{10}$ The reference group are those whose partners always smoked. It reveals that smoking cessation in the relationship is favoured when the partner never smoked or quit smoking during the relationship. This implies an assimilation of the partners with regard to their smoking status.

Model 4 of Table 4 includes additional interaction terms with the couples' living arrangements in order to examine whether assimilation processes differ according to couples' living arrangements. As a result, no significant interaction effects were found. Contrary to our expectations (cf. Table 1) assimilation of partners to one another is not greater in cohabiting couples and in married couples than in couples living apart together.

Finally, Table 6 investigates the hypothesis of assortative matching. The question is pursued of whether not only assimilation occurs with regard to smoking habits over the course of the relationship, but also whether there was homogamy in smoking habits at the beginning of the relationship. For this purpose Table 6 compares the partners' smoking habits at the beginning of the relationship. Controlling for gender, age at the beginning of the relationship and educational level, we ascertain a strong positive effect of the partner's smoking habits at the beginning of

10 Since this is very rare, (29 cases) we did not interpret the effect. 
Tab. 6: Smoking habits at the beginning of the relationship according to smoking habits of the partner at the beginning of the relationship (logit regression, logit coefficients) ${ }^{1}$

\begin{tabular}{lc}
\hline Influencing factor & \\
\hline Man & \\
Age at beginning of relationship & $0.45^{* * *}$ \\
Years of education & 0.01 \\
Partner was smoker at beginning of relationship & $-0.15^{* * *}$ \\
Constant & $1.14^{* *}$ \\
McFadden $\mathrm{r}^{2}$ & $0.70+$ \\
Number of cases & 0.07 \\
\hline
\end{tabular}

Significance levels: ${ }^{* *} \mathrm{p}<0.001 ;{ }^{*} \mathrm{p}<0.01 ;{ }^{*} \mathrm{p}<0.05 ;+\mathrm{p}<0.10$

1 The analyses only refer to people in relationships (i.e. not singles)

2 Reference category: Woman

${ }^{3}$ Reference category: Partner non-smoker at beginning of relationship

Source: Partnermarktsurvey, own calculations

the relationship on the respondent's smoking habits at the beginning of the relationship. This implies that the partners' homogamy in smoking habits results not only (but also, see Modell 3 of Table 4) from assimilation processes over the course of the relationship, but that it is already a consequence of mate selection.

\section{Summary and discussion}

The article examines the effects of couples' living arrangements on smoking habits and body weight using data from the Partnermarktsurvey. The advantage of this data is that it provides information about changes in smoking status and body weight since the beginning of a relationship and that this information is available for both partners, even if the partners do not live together.

The results of this study reveal at first that fewer married people tend to smoke and that they have a higher BMI than people in a LAT relationship. By contrast there are no significant differences between people who do not cohabitate with their mate and people without partners. This indicates that relationship selection is not a decisive reason for the differences in the smoking habits and body weight between couples with different types of living arrangements.

Further results of this study refer to the probability of smoking cessation and considerable weight gain in relationships. These findings show that the chances for smoking cessation during a relationship are greater both among cohabiting couples as well as married couples than among couples living apart together. This indicates that the positive protection effect of relationships on smoking habits is based on 
the mechanism of social control and social support, which is linked to the context of sharing a household. Other results of this study are that the chance of giving up smoking is greater in a relationship if the partner did not smoke or quit smoking since the beginning of the relationship. This implies assimilation by the partner with regard to smoking habits, which occurs among couples living apart together, cohabiting couples as well as married couples. In addition, there is a tendency that partners will have the same smoking habits at the beginning of the relationship, i.e. there is assortative matching with regard to smoking habits in the context of mate selection.

With regard to considerable weight gain during a relationship, there are no differences according to the type of relationship. Neither the hypothesis that weight gain is greatest among married couples because the release from dating market competition is most certain, nor the hypothesis that weight gain is greatest in cohabiting relationships, for instance because of taking meals together, are confirmed.

The results of this study, which indicate a protection effect of marriage on smoking habits, harmonise with results from earlier studies. It enhances the previous state of research by showing that protection can also be assumed for cohabiting couples. Unlike earlier studies that ascribe similarities of mates' smoking habits primarily to assortative matching at the beginning of a relationship (Agrawal et al. 2006; Clark/Etilé 2006), this study reveals both initial relationship selection and assimilation processes. This assimilation in smoking habits during a relationship, which was previously only observed among married couples (Dollar et al. 2009; McBride et al. 1998; Mons 2007), is found among all relationship types. The results for weight gain during relationships, which reveal no differences according to couples' living arrangements, do not concur with existing studies that observe a rise in body weight following commencement of cohabitation (The/Gordon-Larsen 2009).

A number of limitations must be taken into consideration when interpreting the results. For example, this study was unable to clarify the extent to which selection contributes to the observed correlations in the transition to more institutionalised relationship types. We must also consider that people who quit smoking during their relationship are more likely to move in with or marry their partner (tiered selection), or that people who gain considerable weight during their relationship are more likely to marry (adverse tiered selection).

Another limitation is that the information about BMI and smoking habits are selfreported and can therefore be biased due to social desirability. The information on weight gain during the relationship, smoking cessation during the relationship and smoking habits at the beginning of the relationship, which are based on retrospective information, can also be biased by errors in memory. However, in both cases we do not assume that the extent of the bias depends on the couples' living arrangements and therefore that differences between couples' living arrangements should not be affected by this.

Due to the lack of suitable longitudinal information neither the known interaction between smoking and body weight nor the birth of children could be taken into consideration in the analyses. We must consider, for example, that the higher body weight of married people may also be due to their lower smoking prevalence. The 
results of this study, according to which marriage both promotes smoking cessation and favours considerable weight gain, concur with this. As for children, whether or to what extent the favourable effect of marriage and cohabitation on smoking cessation as well as the unfavourable effect of marriage on weight gain during a relationship is caused by the existence of children remains an unanswered question.

As for the question of the significance of the changes in couples' living arrangements for the health behaviour of the population, we can conclude that the decline in marriage and the related increase in cohabitation will not result in any negative effects on smoking habits in Germany. A protection effect for smoking was found for both married couples and cohabiting couples. We also do not anticipate any negative effects on body weight caused by the changes in couples' living arrangements since we observed no correlation between the couples' living arrangements and weight gain during relationships.

\section{References}

Agrawal, Arpana et al. 2006: Assortative Mating for Cigarette Smoking and for Alcohol Consumption in Female Australian Twins and their Spouses. In: Behavior Genetics 36,4: 553-566 [doi: 10.1007/s10519-006-9081-8].

Averett, Susan L.; Sikora, Asia; Argys, Laura M. 2008: For better or worse: Relationship status and body mass index. In: Economics \& Human Biology 6,3: 330-349 [doi: 10.1016/j.ehb.2008.07.003].

Becker, Gary S. 1993: Human capital. Theoretical and empirical analysis with special reference to education. Chicago: University of Chicago Press.

Blackwell, Debra L.; Lichter, Daniel T. 2004: Homogamy among Dating, Cohabiting and Married Couples. In: The Sociological Quarterly 45,4: 719-737 [doi: 10.1111/j.1533-8525.2004.tb02311.x].

Brockmann, Hilke 2008: Gesundheit und Familie. Ein deutscher Testfall. In: Rehberg, Karl S. (Eds.): Die Natur der Gesellschaft. Verhandlungen des 33. Kongresses der Deutschen Gesellschaft für Soziologie in Kassel 2006. Frankfurt am Main: Campus: 910-924.

Brüderl, Josef 2004: Die Pluralisierung partnerschaftlicher Lebensformen in Westdeutschland und Europa. In: Aus Politik und Zeitgeschichte B 19: 3-10.

Carmalt, Julie H. et al. 2008: Body Weight and Matching With a Physically Attractive Romantic Partner. In: Journal of Marriage and Family 70,5: 1287-1296 [doi: 10.1111/j.17413737.2008.00566.x]

Castro, John M. de; Castro, Elizabeth S. de 1989: Spontaneous meal patterns of humans: influence of the presence of other people. In: The American Journal of Clinical Nutrition 50,2: 237-247.

Cheung, Y. B.; Sloggett, $A$. 1998: Health and adverse selection into marriage: evidence from a study of the 1958 British Birth Cohort. In: Public Health 112,5: 309-311 [doi: 10.1038/sj.ph.1900491].

Clark, Andrew E; Etilé, Fabrice 2006: Don't give up on me baby: Spousal correlation in smoking behaviour. In: Journal of Health Economics 25,5: 958-978 [doi: 10.1016/j. jhealeco.2006.02.002]. 
Cohen, Sheldon; Wills, Thomas A. 1985: Stress, Social Support, and the Buffering Hypothesis. In: Psychological Bulletin 98,2: 310-357 [doi: 10.1037/0033-2909.98.2.310].

Craig, Pippa L.; Truswell, A. Stewart 1988: Changes in Food Habits When People get Married. Analysis of Food Frequencies. In: Truswell, A. Stewart; Wahlqvist, Mark L. (Eds.): Food habits in Australia. Melbourne: Rene Gordon: 94-111.

Davis, Maradee A. et al. 1985: Living Arrangements and Dietary Patterns of Older Adults in the United States. In: Journal of Gerontology 40,4: 434-442 [doi: 10.1093/ geronj/40.4.434].

Dollar, Katherine M. et al. 2009: Spousal and Alcohol-Related Predictors of Smoking Cessation: A Longitudinal Study in a Community Sample of Married Couples. In: American Journal of Public Health 99,2: 231-233 [doi: 10.2105/AJPH.2008.140459].

Duncan, Greg J.; Wilkerson, Bessie; England, Paula 2006: Cleaning Up Their Act: The Effects of Marriage and Cohabitation on Licit and Illicit Drug Use. In: Demography 43,4: 691-710 [doi: 10.1353/dem.2006.0032].

Engstler, Heribert; Menning, Sonja 2003: Die Familie im Spiegel der amtlichen Statistik. Lebensformen, Familienstrukturen, wirtschaftliche Situation der Familien und familiendemographische Entwicklung in Deutschland. Berlin: Bundesministerium für Familie, Senioren, Frauen und Jugend.

Ezzati, Majid; Lopez, Alan D. 2003: Estimates of global mortality attributable to smoking in 2000. In: The Lancet 362,9387: 847-852 [doi: 10.1016/S0140-6736(03)14338-3].

Falba, Tracy A.; Sindelar, Jody L. 2008: Spousal Concordance in Health Behavior Change. In: Health Services Research 43,1p1: 96-116 [doi: 10.1111/j.1475-6773.2007.00754.x].

Goldman, Noreen 1993: Marriage selection and mortality patterns: Inferences and fallacies. In: Demography 30,2: 189-208 [doi: 10.2307/2061837].

Gove, Walter R. 1973: Sex, Marital Status, and Mortality. In: American journal of sociology 79,1: 45-67 [doi: 10.1086/225505].

Gross, Christiane; Groß, Jochen 2008: Rational-Choice-Erklärungen zum Rauchverhalten und ihre empirische Relevanz. In: Soziale Welt : Zeitschrift für sozialwissenschaftliche Forschung und Praxis 59,3: 247-268.

Hauner, Hans 1996: Gesundheitsrisiken von Übergewicht und Gewichtszunahme. In: Deutsches Ärzteblatt 93,51-52: A-3405-3409.

Heineck, Guido 2006: Height and weight in Germany, evidence from the German SocioEconomic Panel, 2002. In: Economics \& Human Biology 4,3: 359-382 [doi: 10.1016/j. ehb.2006.05.001].

Helmert, Uwe; Borgers, Dieter; Bammann, Karin 2001: Soziale Determinanten des Rauchverhaltens in Deutschland: Ergebnisse des Mikrozensus 1995. In: Sozial- und Präventivmedizin 46,3: 172-181 [doi: 10.1007/BF01324253].

Huinink, Johannes; Konietzka, Dirk 2007: Familiensoziologie. Eine Einführung. Frankfurt/Main: Campus.

Ikard, Frederick F.; Green, Dorothy E.; Horn, Daniel 1969: A scale to differentiate between types of smoking as related to the management of affect. In: International Journal of the Addictions 4,4: 649-659.

Jeffery, Robert W.; Rick, Allison M. 2002: Cross-Sectional and Longitudinal Associations between Body Mass Index and Marriage-Related Factors. In: Obesity Research 10,8: 809-815 [doi: 10.1038/oby.2002.109]. 
Jöckel, Karl-Heinz et al. 1997: Messung und Quantifizierung soziographischer Merkmale in epidemiologischen Studien. Empfehlungen der Deutschen Arbeitsgemeinschaft Epidemiologie (DAE), der Gesellschaft für Medizinische Informatik, Biometrie und Epidemiologie (GMDS), der Deutschen Gesellschaft für Sozialmedizin und Prävention (DGSMP) und der Deutschen Region der Internationalen Biometrischen Gesellschaft, erarbeitet von der Arbeitsgruppe 'Epidemiologische Methoden' in der DAE der GMDS und der DGSMP [http://www.gesundheitsforschung-bmbf.de/_media/MessungUnd QuantifizierungSoziodemographischerMerkmale.pdf, 23.08.2013].

Kittel, F. et al. 1978: Psycho-socio-biological correlates of moderate overweight in an industrial population. In: Journal of Psychosomatic Research 22,3: 145-158 [doi: 10.1016/0022-3999(78)90018-1].

Klein, Thomas 1999a: Partnerwahl in Ehen und Nichtehelichen Lebensgemeinschaften. In: Klein, Thomas; Lauterbach, Wolfgang (Eds.): Nichteheliche Lebensgemeinschaften. Analysen zum Wandel partnerschaftlicher Lebensformen. Opladen: Leske + Budrich: 207-234

Klein, Thomas 1999b: Pluralisierung versus Umstrukturierung am Beispiel partnerschaftlicher Lebensformen. In: Kölner Zeitschrift für Soziologie und Sozialpsychologie 51,3: 469-490.

Klein, Thomas 2000: Partnerwahl zwischen sozialstrukturellen Vorgaben und individueller Entscheidungsautonomie. In: Zeitschrift für Soziologie der Erziehung und Sozialisation 40,3: 229-243.

Klein, Thomas 2009: Determinanten der Sportaktivität und der Sportart im Lebenslauf. In: Kölner Zeitschrift für Soziologie und Sozialpsychologie 61,1: 1-32 [doi: 10.1007/ s11577-009-0040-2].

Klein, Thomas 2011: „Durch Dick und Dünn“. Ergebnisse des Partnermarktsurvey 2009. In: Kölner Zeitschrift für Soziologie und Sozialpsychologie 63: 459-479 [doi: 10.1007/ s11577-011-0143-4].

Klein, Thomas; Fischer-Kerli, David 2000: Die Zuverlässigkeit retrospektiv erhobener Lebensverlaufdaten. Analysen zur Partnerschaftsbiographie des Familiensurvey. In: Zeitschrift für Soziologie 29,4: 294-312.

Klein, Thomas; Rüffer, Wolfgang 2001: Partnerwahl und Rauchgewohnheiten - Analysen zum Einfluß sozialstrukturunabhängiger Mechanismen der Partnerwahl. In: Klein, Thomas (Eds.): Partnerwahl und Heiratsmuster. Sozialstrukturelle Voraussetzungen der Liebe. Opladen: Leske + Budrich: 163-181.

Klein, Thomas; Stauder, Johannes; Häring, Armando 2010: Gelegenheiten des Kennenlernens. Der Partnermarkt in Ost- und Westdeutschland. In: Krause, Peter; Ostner, Ilona (Eds.): Leben in Ost- und Westdeutschland. Eine sozialwissenschaftliche Bilanz der deutschen Einheit 1990-2010. Frankfurt am Main, New York: Campus: 187-210.

Knuiman, Matthew W. et al. 1996a: Familial correlations, cohabitation effects, and heritability for cardiovascular risk factors. In: Annals of Epidemiology 6,3: 188-194 [doi: 10.1016/1047-2797(96)00004-X].

Knuiman, Matthew W. et al. 1996b: Spouse Correlations in Cardiovascular Risk Factors and the Effect of Marriage Duration. In: American Journal of Epidemiology 143,1: 48-53.

Kurzban, Robert; Weeden, Jason 2005: HurryDate. Mate preferences in action. In: Evolution and Human Behavior 26,3: 227-244 [doi: 10.1016/j.evolhumbehav.2004.08.012].

Laitinen, Jaana; Ek, Ellen; Sovio, Ulla 2002: Stress-Related Eating and Drinking Behavior and Body Mass Index and Predictors of This Behavior. In: Preventive Medicine 34,1: 29-39 [doi: 10.1006/pmed.2001.0948]. 
Lampert, Thomas; Burger, Martina 2005: Verbreitung und Strukturen des Tabakkonsums in Deutschland. In: Bundesgesundheitsblatt - Gesundheitsforschung - Gesundheitsschutz 48,11: 1231-1241 [doi: 10.1007/s00103-005-1158-7].

Lillard, Lee A.; Panis, Constantijn W.A. 1996: Marital Status and Mortality: The Role of Health. In: Demography 33,3: 313-327 [doi: 10.2307/2061764].

MacPherson, Barry D. 1983: Aging as a social process. An introduction to individual and population aging. Toronto: Butterworths.

McBride, Colleen M. et al. 1998: Partner Smoking Status and Pregnant Smoker's Perceptions of Support for and Likelihood of Smoking Cessation. In: Health Psychology 17,1: 63-69 [doi: 10.1037/0278-6133.17.1.63].

Mensink, Gert B. M.; Lampert, Thomas; Bergmann, Eckardt 2005: Übergewicht und Adipositas in Deutschland 1984-2003. In: Bundesgesundheitsblatt - Gesundheitsforschung - Gesundheitsschutz 48,12: 1348-1356 [http://dx.doi.org/10.1007/s00103-0051163-x].

Mons, Ute 2007: Soziale Unterschiede in der Entscheidung zum Rauchausstieg in Lebensverlaufsperspektive. Eine empirische Untersuchung mit Daten des Sozio-oekonomischen Panels. Saarbrücken: VDM Verlag Dr. Müller.

Ng, Debbie M.; Jeffery, Robert W. 2003: Relationships Between Perceived Stress and Health Behaviors in a Sample of Working Adults. In: Health Psychology 22,6: 638-642 [doi: 10.1037/0278-6133.22.6.638].

Noppa, Henry; Bengtsson, Calle 1980: Obesity in relation to socioeconomic status. A population study of women in Göteborg, Sweden. In: Journal of Epidemiology and Community Health 34,2: 139-142 [doi: 10.1136/jech.34.2.139].

Parrott, Andy C. 1994: Individual differences in stress and arousal during cigarette smoking. In: Psychopharmacology 115,3: 389-396 [doi: 10.1007/BF02245082].

Register, Charles A.; Williams, Donald R. 1990: Wage Effects of Obesity among Young Workers. In: Social Science Quarterly 71,1: 130-141.

Robert Koch-Institut (Eds.) 2009: Beitrage zur Gesundheitsberichtserstattung des Bundes. 20 Jahre nach dem Fall der Mauer: Wie hat sich die Gesundheit in Deutschland entwickelt. Berlin.

Ross, Catherine E.; Mirowsky, John 1983: Social Epidemiology of Overweight: A Substantive and Methodological Investigation. In: Journal of Health and Social Behavior 24,3: 288-298 [doi: 10.2307/2136578].

Schulze, Alexander; Lampert, Thomas 2006: Bundes-Gesundheitssurvey. Soziale Unterschiede im Rauchverhalten und in der Passivrauchbelastung in Deutschland. Berlin: Robert Koch-Institut.

Sobal, Jeffery 1999: Sociological Analysis of the Stigmatisation of Obesity. In: Germov, John; Williams, Lauren (Eds.): A sociology of food and nutrition. Oxford: University press: 187-204.

Sobal, Jeffery; Rauschenbach, Barbara S.; Frongillo, Edward A. 1992: Marital status, fatness and obesity. In: Social Science \& Medicine 35,7: 915-923 [doi: 10.1016/0277-9536(92)90106-Z].

Statistisches Bundesamt 2006: Leben in Deutschland. Haushalte, Familien und Gesundheit - Ergebnisse des Mikrozensus 2005. Wiesbaden.

Statistisches Bundesamt 2010: Mikrozensus - Fragen zur Gesundheit. Körpermaße der Bevölkerung 2009. Wiesbaden. 
Stein, Risa J. et al. 2008: Reported Stress and Its Relationship to Tobacco Use among U.S. Military Personnel. In: Military Medicine 173,3: 271-277.

Steptoe, Andrew et al. 1996: Stress, social support and health-related behavior: A study of smoking, alcohol consumption and physical exercise. In: Journal of Psychosomatic Research 41,2: 171-180 [doi: 10.1016/0022-3999(96)00095-5].

Sund, Erik R.; Jones, Andy; Midthjell, Kristian 2010: Individual, family, and area predictors of $\mathrm{BMI}$ and $\mathrm{BMI}$ change in an adult Norwegian population: Findings from the HUNT study. In: Social Science \& Medicine 70,8: 1194-1202 [doi: 10.1016/j.socscimed.2010.01.007].

Sutton, G. C. 1980: Assortative marriage for smoking habits.. In: Annals of Human Biology 7,5: 449-456 [doi: 10.1080/03014468000004561].

The, Natalie S.; Gordon-Larsen, Penny 2009: Entry Into Romantic Partnership Is Associated With Obesity. In: Obesity 17,7: 1441-1447 [doi: 10.1038/oby.2009.97].

Thefeld, W.; Stolzenberg, H.; Bellach, B.-M. 1999: Bundes-Gesundheitssurvey: Response, Zusammensetzung der Teilnehmer und Non-Responder-Analyse. In: Das Gesundheitswesen 61, Sonderheft 2: S57-S61.

Umberson, Debra 1987: Family Status and Health Behaviors: Social Control as a Dimension of Social Integration. In: Journal of Health and Social Behavior 28,3: 306-319 [doi: 10.2307/2136848].

Umberson, Debra 1992: Gender, marital status and the social control of health behavior. In: Social Science \& Medicine 34,8: 907-917 [doi:10.1016/0277-9536(92)90259-S].

Unger, Rainer 2008: Gesundheit im Lebensverlauf. Zur relativen Bedeutung von Kausalgegenüber Selektionseinflüssen am Beispiel des Familienstands. In: Bauer, Ullrich; Bittlingmayer, Uwe H.; Richter, Matthias (Eds.): Health inequalities. Determinanten und Mechanismen gesundheitlicher Ungleichheit. Wiesbaden: VS Verlag für Sozialwissenschaften: 430-451.

Venters, Maurine H. et al. 1984: Spouse Concordance of Smoking Patterns. The Minnesota Heart Survey. In: American Journal of Epidemiology 120,4: 608-616.

Vink, Jacqueline M.; Willemsen, Gonneke; Boomsma, Dorret I. 2003: The association of current smoking behavior with the smoking behavior of parents, siblings, friends and spouses. In: Addiction 98,7: 923-931 [doi: 10.1046/j.1360-0443.2003.00405.x].

Wills, Thomas A.; Shiffman, Saul 1985: Coping and substance use: A conceptual framework. In: Shiffman, Saul; Wills, Thomas Ashby (Eds.): Coping and substance use. Orlando: Academic Press: 3-24.

Wilson, Chris; Oswald, Andrew J. 2005: How Does Marriage Affect Physical and Psychological Health? A Survey of the Longitudinal Evidence. 2005 [http://econpapers.repec. org/RePEc:iza:izadps:dp1619, 23.08.2013]. 
694 - Thomas Klein, Ingmar Rapp, Björn Schneider

Translated from the original text by the Federal Institute for Population Research, for information only. The reviewed and authors' authorised original article in German is available under the title "Der Einfluss der partnerschaftlichen Lebensform auf Rauchverhalten und Körpergewicht", DOI 10.4232/10.CPoS-2013-13de or URN urn:nbn:de:bib-cpos-2013-13de7, at http://www.comparativepopulationstudies.de.

Date of submission: 06.09.2011

Date of Acceptance: 30.11 .2012

Prof. Dr. Thomas Klein $(\bowtie)$, Dr. Ingmar Rapp, Björn Schneider.

Max-Weber-Institut für Soziologie, Universität Heidelberg, 69115 Heidelberg, Germany.

E-Mail: thomas.klein@soziologie.uni-heidelberg.de,

ingmar.rapp@soziologie.uni-heidelberg.de,

bjoern.schneider@soziologie.uni-heidelberg.de

URL: http://www.soz.uni-heidelberg.de 


\section{Comparative Population Studies - Zeitschrift für Bevölkerungswissenschaft}

wWw.comparativepopulationstudies.de

ISSN: 1869-8980 (Print) - 1869-8999 (Internet)

Published by / Herausgegeben von

Prof. Dr. Norbert F. Schneider

Federal Institute for Population Research

D-65180 Wiesbaden / Germany

Managing Editor /

Verantwortlicher Redakteur

Frank Swiaczny

Assistant Managing Editor /

Stellvertretende Redakteurin

Katrin Schiefer

Language \& Copy Editor (English) /

Lektorat \& Übersetzungen (englisch)

Amelie Franke

Copy Editor (German) /

Lektorat (deutsch)

Dr. Evelyn Grünheid

\section{Layout / Satz}

Beatriz Feiler-Fuchs

E-mail: cpos@bib.bund.de

\author{
Scientific Advisory Board / \\ Wissenschaftlicher Beirat \\ Jürgen Dorbritz (Wiesbaden) \\ Paul Gans (Mannheim) \\ Johannes Huinink (Bremen) \\ Marc Luy (Wien) \\ Clara H. Mulder (Groningen) \\ Notburga Ott (Bochum) \\ Peter Preisendörfer (Mainz)
}

\section{Board of Reviewers / Gutachterbeirat} Martin Abraham (Erlangen)

Laura Bernardi (Lausanne) Hansjörg Bucher (Bonn) Claudia Diehl (Göttingen) Andreas Diekmann (Zürich) Gabriele Doblhammer-Reiter (Rostock) Henriette Engelhardt-Wölfler (Bamberg) E.-Jürgen Flöthmann (Bielefeld) Alexia Fürnkranz-Prskawetz (Wien) Beat Fux (Zürich) Joshua Goldstein (Rostock) Karsten Hank (Köln) Sonja Haug (Regensburg) Franz-Josef Kemper (Berlin) † Michaela Kreyenfeld (Rostock) Aart C. Liefbroer (Den Haag) Kurt Lüscher (Konstanz) Dimiter Philipov (Wien) Tomáš Sobotka (Wien) Heike Trappe (Rostock) 